\title{
(息)
}

Citation:

Flintoff, A and Dowling, F (2017) 'I just treat them all the same, really': Teachers, whiteness and (anti) racism in physical education. Sport, Education and Society. ISSN 1357-3322 DOI: https://doi.org/10.1080/13573322.2017.1332583

Link to Leeds Beckett Repository record:

https://eprints.leedsbeckett.ac.uk/id/eprint/3756/

Document Version:

Article (Accepted Version)

The aim of the Leeds Beckett Repository is to provide open access to our research, as required by funder policies and permitted by publishers and copyright law.

The Leeds Beckett repository holds a wide range of publications, each of which has been checked for copyright and the relevant embargo period has been applied by the Research Services team.

We operate on a standard take-down policy. If you are the author or publisher of an output and you would like it removed from the repository, please contact us and we will investigate on a case-by-case basis.

Each thesis in the repository has been cleared where necessary by the author for third party copyright. If you would like a thesis to be removed from the repository or believe there is an issue with copyright, please contact us on openaccess@leedsbeckett.ac.uk and we will investigate on a case-by-case basis. 
Paper accepted for Sport, Education and Society, May $16^{\text {th }} 2017$

'I just treat them all the same, really': Teachers, whiteness and (anti) racism in physical education

Anne Flintoffa and Fiona Dowling ${ }^{\mathrm{b}}$

a. Diversity Equity and Inclusion Research Centre, Carnegie School of Sport, Leeds Beckett University, England

b. Department of Cultural and Social Studies, Norwegian School of Sports Sciences, Oslo, Norway

Anne Flintoff, Carnegie School of Sport, Fairfax Hall, Headingley Campus, Leeds Beckett University, Leeds LS6 3QS a.flintoff@leedsbeckett.ac.uk ; ORCID: 0000000043842000 


\section{'I just treat them all the same, really': Teachers, whiteness and (anti) racism in physical education}

This paper explores physical educators' perspectives on race and racism as a first step towards disrupting whiteness and supporting the development of antiracist practice. With close links to sport, a practice centrally implicated in the creation and maintenance of racialised bodies and hierarchies, Physical Education (PE) offers an important context for a study of whiteness and racism in education. Using collective biography we examine physical educators' narrative stories for what they reveal about the operation of whiteness and racism in PE. Teachers draw on narratives from curricula texts which uphold and reinforce notions of the racialised other, thereby reasserting normative, universal white knowledge. Their pedagogy is underpinned by a colour blind approach where race is "not seen', yet essentialist and cultural discourses of race are nevertheless deployed to position particular racialised and gendered bodies as 'problems' in PE. Engagement with antiracism is limited to professional rhetoric within pedagogical practice.

Keywords: whiteness, race, physical education, teachers, antiracism, collective biography 


\section{'I just treat them all the same, really': Teachers, whiteness and (anti) racism in physical education}

\section{Introduction}

This paper draws from a wider project that aimed to explore physical educators' perspectives on race and racism as a first step towards disrupting whiteness and supporting the development of anti-racist practice in the subject (Flintoff and Dowling, 2014). Whilst education and schooling have long been identified as important contexts for challenging racism, Physical education (PE) as a specific subject area has rarely been included in these analyses. Despite being legitimated as a subject contributing to the development of students' embodied identities and health and wellbeing, PE is nevertheless often positioned as marginal to the broader goals of schooling. Nevertheless, due to its close links with sport, a practice centrally implicated in the creation and maintenance of racialised bodies and hierarchies (Hylton, 2008) we argue PE offers an important context for a study of whiteness and racism in education. The fact that PE practitioners and scholars in western countries are an overwhelmingly white group (Douglas and Halas, 2013) not renowned for their critical reflection on equity issues, lends further weight to our contention.

Our research responds to calls from those working within critical whiteness studies to shift our gaze as researchers from the inadequacies of 'others' or from the race relations between 
'us' and 'them', to whiteness as a system of privilege (Gillborn, 2008; Levine-Rasky, 2002). Hegemonic beliefs and practices about race tend to position whites as 'normal' and racially 'unmarked', and 'others' as 'deficit' and 'named'. The limited research about race and PE has tended to adopt such an approach, focusing, for example, on the underrepresentation of black and minority ethnic (BME) youth in physical activity participation figures, or the so-called 'problem' of Muslim girls (e.g.Walseth, 2013). In contrast, critical whiteness perspectives highlight that we are all positioned within race relations that exist in a given social and historical moment, distributing unequal access to power. The intersections of gender and class with race are important aspects of how these relations are differently experienced. Although more evident within broader educational research (particularly in North America), critical analyses of whiteness in PE are still in their infancy. Exploring how white physical educators make sense of race in contemporary policy contexts offers the potential to create new knowledge about whiteness, racialisation, embodiment and education, and support work towards the development of an antiracist pedagogy within PE.

Our study included white school and university teachers working in PE and Sport Science from England and Norway, countries with very different histories in relation to colonialism and immigration. However, both have continued to see significant shifts in their populations, particularly more recently, in relation to the increased diversity of young people of school age (Department for Education, 2014a; NOU, 2014:7) $)^{\mathrm{i}}$. Our research sought to examine how discourses of race and whiteness are constructed within PE as a 
specifically embodied subject. Drawing on data resulting from engaging in a process of collective biography, we present a critical examination of physical educators' individual and shared narrative stories for what they reveal about the operation of whiteness and racism in PE. The research aim was to examine what discourses of race are found in white physical educators' narratives?

\section{Race in education and physical education}

Physical educators' understandings of race reflect their biographies, their initial and continuing professional development, and the nature of public and professional discourse on which they are able to draw. By situating our research within two national contexts, we aimed to examine the contextual constraints and possibilities of constructions of race within policy and practice, but also to identify commonalities across national boundaries. For example, England and Norway have contrasting histories in relation to immigration; England has had large scale immigration since 1945 and an established multicultural society whereas Norway's immigration policy has been more recent (since 1970s) and relatively restrictive (Gullestad, 2006). Education and schooling in both countries are also quite different: Norway's national curriculum has a long 200 year history, whereas in England, the introduction of free schools and academies, free to develop their own curriculum and organisation, coupled with a well established private school system, undermines the very notion of a national curriculum (House of Commons Library, 2014). The position of PE within the wider school curriculum also differs; in England, externally examined PE is optional at years 16 and 18 whereas in Norway it is compulsory and 
contributes to a student's overall assessment grade at 16 and post-18 years. Some of these differences are evident within the examples of the narratives presented below.

Notwithstanding the differences, several common themes and shifts about race are evident in both countries' educational policies within the postwar period (see for England (Tomlinson, 2008; Norway - NOU, 2010:7). In both, policy rests/has rested upon ideas associated with pluralism, anti-racism and equity on one hand, and antipluralist, racist and anti-immigration on the other (Gillborn, 2008) ${ }^{\text {ii. }}$. The dominant storylines of race can continue to be characterised as those of "normalised absence or pathologised presence'(Pheonix, 2009): that is, racialised others ${ }^{\mathrm{iii}}$ are either ignored in policy discourse, or viewed through a 'deficit' lens as 'lacking' in relation to a white 'norm'. Most recently, concerns over immigration into Europe and ongoing incidences of terror have resulted in heightened attention towards 'others' and concomitant increased emphasis upon the importance of cultural and national identity - on what is means to be 'British' or 'Norwegian'. For example, in the UK, teachers are now required to teach 'British values' (Department for Education, 2014b) and along with university lecturers, report pupils and students at risk of 'radicalisation'. In Norway, Beidlid (2012) demonstrates how religion is a central part in the construction of national identity, whereby Christian values are conflated with universal ideas about human rights, and in so doing, firmly positions nonNorwegians and peoples of other religions as 'others'. Gillborn (2008) maintains that social control and integration are again becoming central in contemporary educational discourse around race. 
At the same time as schools are becoming increasingly differentiated in terms of their pupil intake, analyses of initial teacher education (ITE) reveal significant concerns over how student teachers are prepared to engage with issues of race (Lander, 2014; NOU, 2010:7). Smith (2013) shows the ways in which deficit models of difference, and an assimilationist approach to race are reproduced within the latest teacher standards in England. Lander (2014) and Wilkins (2014) go further and argue that the recent history of race within the ITE curriculum is one of 'progressive erasure'. In Norway, research on racism has generally been marginalised in academia or tends to be given a narrow scientific definition or perceived as an individual, rather than as a structural and institutional phenomenon affecting everybody (Gullestad, 2006). Acknowledgement of pupils' multiple identities, or the ways in which race intersects with gender or social class to qualitatively impact on experiences of racism, is also largely invisible. Such policy contexts leave the few committed teacher educators that are engaged in race equality work to do so largely in isolation. It is not surprising, therefore, to learn that student teachers' responses to this work are varied (Gaine, 2001) or that many newly qualified teachers in England continue to feel underprepared to work with pupils from minority ethnic backgrounds (National College for Teaching and Leadership, 2015). In addition, despite their important role in preparing future teachers, reflections by white teacher educators in relation to their own position in educating about race and racialisation in ITE remain rare (Johnson Lachuk and Mosley 2011; Pearce 2003; Harlap and Riese 2014).

The dominant discourse of race in schools, in both countries, is also closely linked to a deficit model of difference, evident, for example, in the ways in which schools' 
'performances' are measured. Whilst useful for revealing broad trends, quantitative analyses that draw on categorical data (such as gender, ethnicity and so on) may also work to construct difference. In England, Gillborn (2008), for example, has shown how league tables compare schools, and within schools, different groups of students, on the basis of performance in national assessments, allowing for the construction of (particular) racialised others as 'lacking'. Likewise, Bakken and Elstad (2012) have pointed to the ways in which school assessment practices can construct rather than challenge race inequality.

In PE specifically, its strong links to sport means that it is a subject saturated by relations of race, gender and class (e.g., Evans and Davies, 2006; Hylton, 2015; Kirk and Vertinskyj, 2016). The media plays a central role in reproducing creation and maintenance of racial categories through sport (Hylton, 2008): particular bodies have been validated, others denigrated, and the biological racism central to colonial times can be seen to underpin black and minority ethnic (BME) communities' experiences of contemporary sporting practice (Long et al., 2009). Although a sustained analysis of race and PE is still required, existing research points to the ways in which racialised discourses are also upheld within PE. Teachers continue to hold essentialised and contradictory views of students' capabilities and bodies on the basis of their ethnicity (e.g., Azzarito, 2009; Fitzpatrick, 2013) and biological racism gets reproduced through 'official' knowledge in PE (Dowling \& Flintoff, 2015; McDonald, 2013).

\section{What can a critical whiteness lens offer?}


It is from this rather unpromising context mapped above that scholars are increasingly arguing for a reframing of race relations work towards a critical analysis of whiteness as a set of practices and a system of power relations. A critical whiteness lens positions white educators firmly inside of race, centralising white curricula, and teachers' pedagogies and practices within the processes of racialisation (Levine-Rasky, 2000). Understanding whiteness as a racial discourse (rather than simply the attributes of white people) it is possible to explore how white cultural practices as promoting a certain racial hierarchy and distribution of embodied capital and rights.

A focus on whiteness allows for an examination of power at work in the social and political processes through which racially distinct groups are constituted and become meaningful in given contexts (Garner, 2007). Central to the notion of whiteness is the recognition that as an identity it only exists in relation to other racialised identities and its meaning is not fixed, but context-dependent (for example, in relation to ideas about the nation and geopolitical and socio-historical boundaries). Whiteness works to exclude and include, 'distributing entitlements to opportunity, treatment, and good for some, and prohibition to participation, services and good for others' (Levine-Rasky, 2013,16). In Norway, for example, the Sami have historically been, and some would argue continue to be, awarded lower status and access to resources than ethnic Norwegians (Gullestad, 2006). Whiteness is also always constructed in relation to other social divisions such as gender and social class. By focusing on whiteness as socially constructed, rather than something essentially linked to white bodies, avenues for change are possible. 
Adopting a critical whiteness lens entails acknowledging and challenging its seeming invisibility (Dyer, 1997). Gabriel (1998) argues that such invisibility is maintained through the discursive tools of naturalisation, ex-nomination, and universalisation. Elsewhere, we have found these tools useful in order to begin to examine how whiteness works within our own work within PE teacher education (PETE) (Flintoff, et al, 2014) and the PE curriculum (Dowling and Flintoff, 2015).

\section{Methodology}

Drawing on Davies and Gannon (2006), we used collective biography to generate data. Collective biography starts with participants first writing, and then sharing, short biographical narratives- in this case, about their upbringing, formal education experiences, (un)awareness of whiteness and the concept of race, and teaching about ethnicity and race in PE and PETE. The aim of the stories is not so much to understand the specific details of individual lives, but rather to examine the thoughts and practices of physical educators who constitute themselves and are constituted as experiencing subjects. Memories are inevitably social constructions weaving the personal, the social and the historical together, and accordingly, they can be analysed as cultural texts (McLeod and Thomson, 2009).

Our participants were ten white teacher educator (5 from each country) and 8 PE teachers (4 from England, 3 from Norway), and we also took part in the research as researchers/teacher educators ${ }^{\text {iv }}$. Recruitment of our participants was not necessarily easy, particularly in relation to the school teachers, and we had to rely heavily on our professional networks. We aimed to recruit participants with different teaching experiences 
and backgrounds; in practice, all but one of our teachers were men, and all but one of our teacher educators were women, perhaps reflecting gendered leadership in PE (Webb and Macdonald, 2007) and the increasing feminisation of teacher education (Dillabough and Acker, 2002). The participants' self declared ethnic backgrounds were either 'white Norwegian' or 'white British' and, as might be expected, our teacher educators were older than the teachers working in school. Many participants had limited experience of working with racialised others, either at school or university.

We each wrote a set of short narratives drawing upon our biographical experiences before the texts were then shared and critically reflected upon in the course of group dialogues that lasted up to 3 hours. The group dialogues were transcribed and analysed, representing a further layer in the deconstruction process. We then interrogated the texts in order to address a number of questions: How do we articulate and construct race and ethnicity in PE and PETE cultures? What truths about race produce what types of discourses in PE and PETE? Our use of discourse draws upon Foucault. Discourses are 'practices that systematically form the objects of which they speak. Discourses are not about objects; they constitute them and in the practice of doing so conceal their own invention (Foucault, 1972, cited in Flintoff and Fitzgerald, 2012). We were interested in the social conditions that hold these constructions of race and ethnicity in place. In what ways are they made to seem evident, fixed and apparently unchangeable? In pursuing these questions, we sought to make these 'truths' more fluid and more open to other possibilities. Our purpose was to analyse fragmentary stories, some of which we share here, in order to reveal the social effects and processes of whiteness as one step towards being able to dismantle them and 
ultimately work towards more inclusive, anti-racist PE. However, one of the mechanisms by which whiteness works is through silencing of 'race talk', and whilst our methodology was designed to establish a certain level of trust between us, there were clearly times when 'whiteness-at-work' (Yoon, 2012) was evident in our conversations. We return to this fundamental challenge of the research below.

\section{Whiteness at work within the PE/PETE curriculum}

I undertake a lecture on ethnicity as part of the first year Equality and Diversity in Sport module at [university]. I was perhaps more nervous about the delivery of the lecture on ethnicity than the other social divisions ...It's a subject that I have the least knowledge. If I'm being honest, it's been of the least interest to me throughout my academic career. I've never really had it crop up as an 'issue' in my life.

... When the students were seated, I'd picked out the two Black students in the year group straight away. I have no idea why, but I hoped that they'd find this particular lecture interesting and that what I said was okay with them. I'd never taught students about ethnicity and sport participation before, and the module was new, so I'd prepared the lecture from scratch. It's only subsequently that I've realised that I fell into the trap of focusing all of my attention on BME (black and minority ethnic) groups! No mention of whiteness, only a discussion of Britishness according to the British Social Attitudes Survey (Janet ${ }^{\mathrm{v}}$, English teacher educator). 
Janet's narrative above reflects the ways in which many of our teacher educator participants positioned themselves in relation to curriculum knowledge about race: although accepting of their professional obligation to address race, this was discharged within superficial, 'oneoff' sessions focused on the racialised other, rather than whiteness and racism. Similarly, our teachers' narratives around curriculum knowledge and their understandings of inclusive practice, cohere with the discursive techniques revealed in our more detailed examination of national curricula PE policy within the two countries (see Dowling and Flintoff, 2015). We concluded there, that it is through such discursive construction of notions of 'fair play' as bearers of values like respect and tolerance that the power that upholds their status is obscured. National curriculum documents in PE, in both countries, reinforce the binary of 'them' and 'us'. The taken-for-granted physical activities that comprise much of PE's official knowledge are presented as universal and normative, with their cultural and social historical roots (including the legacies of colonialism and Eurocentric ways of reasoning) overlooked. The documents we examined exhibit a passive ‘anti- discriminatory' approach, rather than actively promoting race equality that works towards changing institutional cultures and practices (e.g. Commission for Racial Equality, 2002; BLD, 2013). These discursive techniques are evident in the following discussion between our Norwegian teachers about the nature of the PE curriculum:

(Simen): Well, it's up to the individual teacher ...you're meant to have activities that reflect the students etc ...but what's actually written in the curriculum there's nothing more than a reference to dance from other cultures (interrupted) 
(Tord): No, there is the possibility to choose sports that are ...that are more central to other countries' cultures, like cricket which is really big in India... but I've never taught it. Table tennis is really big in Asia but I've never taught that. So there's room, it's possible, but ... (Simen): No we don't think like that. I think about the principle of 'fair play' - that is claimed to provide lots of possibilities. And it provides room for...inclusion and making sure that all have a chance to take part...

(Vetle): I try at the same time to be a bit conscious about it (youngsters with different backgrounds)...we try to avoid the main team games and rather offer a broad spectrum of activities...be a little flexible

(Simen): Is it possible, though, to let them down if the aim is integration and assimilation isn't it the point of school to offer skiing. Isn't that a desired goal?

Although there are always possibilities for teachers to resist the dominant discourse, our narratives, as the one we have shared above, reveal few examples of this in practice. Rather, instead, we found traces of essentialist beliefs about race, such as the idea that Black athletes are superior athletes or that White Norwegians have a 'ski gene'. In particular, narratives constructed by older teacher educators were laced with examples of essentialist ideas. For example, one Norwegian teacher educator recalled an exhibition, 'Africa Calling!' in which mud huts and spears were exhibited at a local fete, as an exotic fairground attraction and as a means of generating income in order to carry out missionary work. In other words, imperialism lurked in the shadows of the texts. Similarly, texts constructed by younger teacher educators momentarily disrupt such images with stories of a more multicultural society, reminders of the historical as well as social influences on the 
discourses - for example, talk about how one's children attended multicultural urban schools.

Despite the contradictions in the texts, the teacher educators paint a picture of race and (anti)racism in PETE as peripheral knowledge. It's often constructed as a variable, if it's addressed in the formal curriculum at all:

You can talk about changing attitudes or try to talk about it differently or within a social inclusion paradigm but as long as you keep to reporting sociological variables ... you end up talking about Muslim girls, for example (Norwegian teacher educator's dialogue)

The formal curriculum in both school and university upholds and reinforces the racialised other and thereby reasserts the normative, universal white position. As these texts illustrate, educators draw on white experience and knowledge to count for the experiences of everyone in PE, and in so doing, deny the presence and impact of racism on the lives of racialised others. Racialised others are also constructed in opposition to white bodies through teachers' stereotyping of students' abilities, reflected within their pedagogy, as the next section highlights.

\section{I treat them all the same - colour blind pedagogy}

$\mathrm{PE}$ and sport have long been seen as meritocratic spaces, 'level playing fields' where everyone has equal access and opportunity to do well and be rewarded on merit. A rationale 
sometimes voiced about PE is that it offers an alternative way for young people not able to demonstrate 'academic' ability to shine - for them to show, and be credited for, their physical abilities. As such, PE constitutes the ideal space for the deployment of colour blind discourses in the narratives - for 'not seeing' racialised bodies, only able bodies. Many of our teachers stressed that they 'didn't see race', but treated all students as the same. As Tord and Neil suggest,

like in football, I think it's very positive not seeing skin colour... but I'm not talking about culture...but referring to how someone with dark skin can play on the same team with someone with Asian features or someone who's Norwegian looking... if I see that as being colour blind, then that's very positive...(Tord, Norwegian teacher)

To us, though, colour was irrelevant; what we wanted to know was who was the better player and who could come on our side to us, had ability with the ball... we wanted him because he was massive and able to belt the ball and that was it, it was...game on! (Neil, English teacher)

Nevertheless the texts reveal it is particular kinds of the abilities and bodies that are valued and promoted, closely linked to ideas of national identity and taken-for-granted notions of 'our' shared physical culture. Elsewhere we have noted how curricula texts assume notions of 'our' shared physical culture, and that everyone will want to engage enthusiastically in our 'national' sports of football or skiing as a result (Dowling and Flintoff, 2015). Having 'others' in our class belies these assumptions, presents challenges to our established 
pedagogical practices, and in so doing, reveal the workings of whiteness at work, as this dialogue between Norwegian teacher educators illustrate:

We were due to have a day out skiing. It'd been on the programme all year. ...there were about 70 students in the auditorium and this African student asked some critical questions about why it should be mandatory for all students. She didn't own any skis and said she'd received far too little information about the day... There ensued an exchange of views and I began to feel very uncomfortable with the entire situation. The student began to cry....She was overweight, Black and had a cultural background that didn't include skiing. I was unsure as to how I ought to react...

... I certainly don't think we should stop having a ski day, though, just because some students don't like the idea of it and think it's difficult!

Colour blind pedagogy, that draws on liberal notions of meritocracy and equal treatment but with little appreciation of the impact of structural racism on educational experiences, results in students like this being repositioned as 'bodies out of place' - constructed in opposition to the mesomorphic, white, and privileged (and male) ideal (Azzarito, 2009; Fitzpatrick, 2013). Whilst white teachers cannot fail to see race in these situations the discursive effect of universalism - where white knowledge and experience is taken as universal - ensures that is the 'others', rather than the teachers' pedagogies, that are positioned as 'problems' or 'lacking'.

Emotions were also a clear underpinning of the narratives, particularly fear, emanating from stereotypical assumptions of particular racialised embodiment: 
I did feel a bit worried about teaching BME (black and minority ethnic) pupils as ...I'd wrongly thought that they were often loud... and difficult to control... [because] when I was training, this is what it felt like. It's probably a mixture of inexperience...but in my first few weeks at my new school, there was a huge line ... who would walk round school and intimidate other people, they were some of the hardest pupils to teach and were really tall as well. So they were, physically like...you'd be telling them off, looking up, but I did go in thinking they were all going to be - this is awful isn't it? - but at the time I was worried they were all going to be like that particular group of lads (Harriet).

Stereotypes of racialised male bodies that recurred in the narratives point highlight the ways in which racialised discourses are always enmeshed with those of gender and class and how whiteness is very much contingent. Immigrants from Poland or other Eastern European countries are still 'othered' as different, and seen as lacking because 'cultural differences' or a lack of experiences in 'our' physical activities. The narratives also revealed discourses relating to a teacher's own embodiment as central to pedagogical relations in PE. Harriet's fears as a young teacher about whether she would be able to manage the behaviour of 'big and loud' boys draw on the stereotypes of the 'dangerous' black male body (Carrington, 2011). Men and women are positioned, and position themselves, as 'effective' teachers within the gendered and racialised discourses that circulate within the hyper-embodied field of PE (Flintoff, 2013; Mooney and Hickey, 2012), as the following interchange illustrates: 
I was thinking like how in PE departments guys are often - this is a stereotype - some men are very reluctant to teach like year 11 girls ....aren't they and I guess that is slightly on the sexist assumption that all girls will be...lazy, really hard work and stuff. But can you imagine [if] it was full of like ...black people, we'd be like, I don't want to teach that class because...it would never happen would it? But yet, it's totally acceptable, I don't want to teach that year, they're all girls, they're on football, they're not really fit (Harriet, English teacher).

You're right...I've taught a few girls' classes over the years and I've got some now, I always find it that bit harder to relate to the girls than I do the boys when I'm teaching them, you know, and I'm quite happy to say that, but I would never dream of saying that about, like you said... if there is a group black boys or girls in a class, you know, I'd never think, oh I don't quite relate to them the same and feel comfortable saying that (Dan, English Teacher).

Pennington and Prater (2016) point to the importance of 'white talk' as a key aspect of how whiteness works as a way to 'derail' conversations about race, such as the use of silence or hyperpoliteness when discussing race or, as above, slipping into talking about gender instead, something that's easier or more 'acceptable'. Through our education and experiences as teachers, we've learnt to adopt a professional rhetoric around race that works to silence more deeply held fears, and as we explore below, that are often longstanding .

\section{Developing a professional rhetoric of (silencing) race}


Our participants' experiences of living and working with racialised others had changed since childhood, and fear was a key emotion evident within many of the narratives about these earlier experiences:

When I started school there weren't many immigrants just whites ... but in the course of the 6 years I was at primary school they arrived ... I remember all the stereotypes... I'd never met a Pakistani person or a Turk ....and it became very much of a 'them' and us' thing ...They spoke a different language and they behaved differently, they really did! And I remember you could be a bit afraid of 'those boys' if you said something wrong and the like...there was a type of gang mentality. (Tord, Norwegian teacher)

Other than seeing an elderly black man walk past the end of my street sometimes...I never really had to speak to anyone outside my own race. At seven, I started karate... after school [where] I was greeted by a six foot something black man as my instructor. Although this posed no issue... I remember my mum saying, 'oh, Chris has started karate, oh and there is a big black instructor, hasn't he done well to be put into that environment... it were (sic) noted...yes, had that been just a white person it wouldn't have been mentioned. (Dan, English teacher)

Growing up in 'white' neighbourhoods and attending 'white' schools in both countries, the teachers' stories from childhood revealed their limited interactions with racialised others, who were constructed as 'different', and as people to be wary of, avoided, or feared. These also show the shifting nature of historical discourses of race, reflecting population changes across both countries. Our teachers struggled to reflect on their racial identities, focusing 
instead on those of others, recounting stories of first meetings with racialised others. Similar narratives were recounted by the teacher educators. Picower (2009) argues that whiteness is maintained through three sets of 'tools', which she calls ideological, emotional and performative tools. Here the deployment of ideological tools, or the beliefs to which individuals subscribe to protect their hegemonic stories are revealed - in this case, their beliefs that seek to minimise, deny or individualise racism (Bryan, 2012). Our participants were keen to distance themselves from what they saw as the more 'overt' racist practices reminiscent of their parents' generation, through deploying a more 'progressive', 'colour blind' discourse of race. Race is 'not seen'; racial differences 'not acknowledged', and racism is regarded as belonging to past generations, when parents 'didn't know better'. As Mary suggests:

Today's generation is a product of many different cultures, ethnicities and races so the ignorance of previous generations is gradually fizzling out. Everyone has a story about a grandparent, a crazy aunt or even a parent who has said something cringe-worthy, questionable and completely lacking in political correctness. I think we often take these comments with a pinch of salt (maybe a whole shaker in fact) because we are aware of the systems that were in place in the past. In my case, there was definitely no malicious intent behind some of these comments from family members, but a lack of education and understanding when it came to BME members of society (Mary, English teacher educator)

Although many of our educators talked about fighting for inclusive practice and equal rights, nevertheless, negative stereotypes about racialised others are woven into the texts- 
such as the fear of others being violent, criminal, and dangerous. Intellectually these racist beliefs are rejected, but across a range of contexts (at home and abroad) embodied reactions are practically impossible to avoid, illustrating how the normativity of whiteness against which racialized others and lives are defined as being inferior, and is internalised early on in childhood. There was little evidence of whiteness having been challenged through our pre or in-service teacher professional development, reflecting the research findings of Lander (2014) and Skrefsrud and Østberg (2015). A fundamental challenge of working to dismantle or disrupt whiteness, either through research or teaching is to recognise that we are always enmeshed with it, always attempting to work through whiteness. We have reflected on how our research process itself could contribute to, rather than challenge whiteness (see Hylton, 2012; Pennington and Prater, 2014). A key strategy of white silence, where we switched to talking about gender or class rather than race, was evident in our narratives:

(Neil) I was going to say, we've talked haven't we, how teachers are reluctant to talk about race, and yet that's the thing that is probably dealt with, one of the most serious issues in school isn't it, racist behaviour or attitudes. But if you were compare that to gender, we're all very happy to talk about gender aren't we, and yet if someone said something sexist at school, I don't know, you'll probably know a bit more than me [directing his comment at Harriet], but it's not dealt with. 
(Harriet) I think it's odd that race is the one we don't want to talk about ....and yet gender we're happy to talk about... we're not hauling in kids for saying sexist things in the same way we might for racism.

(Neil)You don't have a book ${ }^{\mathrm{vi}}$ to record down gender incidents, and yet you do for the local authority in terms of racism.

(Dan) Is it to do with...I might be wrong here, is it to be do with law, because to be sexist is not illegal. Am I right to think that?

(Author) No, you're wrong

(Dan) Oh, I'm wrong. So it is illegal to be sexist?

\begin{abstract}
A second text from the Norwegian teacher educators' conversations shows a similar reluctance, and extends the reflection to include the challenge of dealing with racism in everyday classroom interactions between pupils:
\end{abstract}

It's interesting to note that when we talk ... we're meant to be talking about racist incidents etc, but we natter on about everything else under the sun! We're struggling a bit to talk it...

Where I work, we try to be a showcase for multiculturalism because as you know, we do have a considerable number of ethnic minority students. We've all manner of strategies and the like! But I remember I had a group where there was a bit of racism going 
on... something about the learning environment. There was a strong leader in the group who was very funny, amusing. Plus a couple of others, too. And the teaching staff loved them in a way. Clever and engaged, you know. But they could use jargon about foreigners in the class that was borderline. Like, one time I overheard, 'Heh, you Paki, pick up my rubbish'. Joking but ... And it's like a question of when do you react? How many comments are too many? It's difficult to put your finger on something, but it's there, racism is there but you don't know how to deal with it.

The narratives reveal how as teacher educators we are ill-equipped to teach about race in PETE, a discourse that saturates the texts from the perspectives of lacking formal education, of lacking knowledge about antiracist policies at national and institutional levels, and not least, of the technique of 'supplanting whiteness' (McKinney, 2005). Other social divisions, such as gender or class, are constituted as more salient denying the importance of whiteness, as illustrated in the first narrative. Whiteness was evident within the collective biography methodology we chose for this research in the ways in which we struggled to talk race. Analysing the 'truths' in these narratives, shows how race is constructed in relation to others, leaving whiteness unmarked. It is the black and Pakistani students who are named. As highlighted above, race is more often taught in one-off sessions, rather than being conceptualised as affecting all aspects of PETE, and the 'hidden curriculum' therefore plays a significant role in how race is constructed, like the incident of so-called humoristic student banter. As Essed (2005) observes, joking is a common mechanism for reconfirming the norm of whiteness in everyday racist discourse. 
Similarly, the teacher educators' discourses situate them beyond race and ethnicity - it's the others (you might have in front of you) that are marked. This discourse is upheld by PE student teachers, too:

Bob and Jack, two white British students, and Salim, a British Asian student, are sat around a table in a sport sociology seminar. I walk over. "So, tell me," looking at the whole group, "how do you think race has affected your own sport engagement?"

Bob turns to his left. "Salim?"

There is a second of silence.

It is the answer I anticipated and dreaded at the same time, yet it still deflates me.

It is only Salim who can answer, only Salim whose experiences have been shaped by his race, his visible Asian racial identity, his visible difference to Bob, whose white skin means nothing, does not signify a racial identity at all, and can have had no impact on his access to sport or his experiences when playing. (Josie, English teacher educator)

Here, we do actually witness a discourse that acknowledges the significance of whiteness, but these competing storylines are far less evident in our analyses. How teachers think about and act in race and gender equality reflects the availability of institutional discourses of race and gender on which to draw. Most often, for these teachers, racism and sexism are understood as individualised acts or incidents rather than structural power relations reproduced by institutionalised practices. Racism is exceptional, extreme and scarce 
incidents that need to be recorded 'in the book' rather than conceived as 'the more subtle and hidden operations of power that have the effect of disadvantaging one or more minority ethnic groups (Gillborn, 2008:7). In doing so, white teachers can position themselves largely outside of race, and in a similar way, Neil (as highlighted earlier) is able to divest himself of responsibility for challenging sexism. Working in single sex PE classrooms, he can deny knowledge of his privileged positioning as a (white) man, since he only teaches boys. For Dan, since sexism is not (in his knowledge) illegal, it doesn't count. By drawing on discourses of racism (or sexism) that define it as individual acts rather than reproduced through the curriculum, teachers' and institutional practices, teachers are in effect able to deny their role in whiteness.

\section{Concluding comments}

Our research sought to examine the ways in which whiteness operates within PE and PETE as a first step towards the development of an antiracist practice. The use of a collective biography methodology with white educators allowed us to 'switch the lens' from racialised 'other' to explore how whiteness works within PE and how we, as teacher educators and teachers, are both positioned and advantaged by its operation. The research has revealed the dominant discourses of race on which we draw to make sense of our practice.

Despite their very different national and political contexts, our research reveals striking continuities in the ways in which teachers' pedagogy in both countries upholds and reinforces notions of the racialised other, thereby reasserting the normative, universal white 
position. The activities might differ somewhat - a bit more skiing in Norway, or major team games in England - but our pedagogy centres on taken-for-granted activities unproblematically positioned within national curricula texts as important aspects of 'our' shared heritage. Our engagement with race can be, at best, characterised as being limited to professional rhetoric. As educators our commitments to inclusive pedagogies are undermined by colour-blind approaches of not 'seeing race'. Yet, as a particularly embodied subject, our research has shown how teachers draw upon essentialist and cultural discourses of race serving to position different bodies as revered, feared or 'problems' in contemporary PE. Racialised discourses about the body intersect with those of gender and class to have material effects on the opportunities and achievements of racialised others within PE (whilst privileging those of white students and teachers). We have to work hard to 'not see race', by drawing on equal opportunities rhetoric, downplaying fears of the racialised other, and rationalising our limited engagement with challenging racism through positioning it as individualised actions, rather than structural power relations constructed through schooling, curricula and our own practice.

Engaging in whiteness is challenging for white physical educators, not least, as highlighted above, such an approach is always 'in tension'. We have pointed to some of the ways in which these tensions were evident in this research. We also remain mindful of Pennington's $(2007,111)$ point, drawing on bell hooks, that 'there are dangers when White ...educators and researchers work on racism exclusively with other Whites' to the exclusion of racialised others'. We agree that there is the danger that we simply validate views that we are attempting to dismantle. However, challenging the invisibility and 'taken-for-granted' 
nature of whiteness and its operation will involve us in being prepared to take the first steps towards 'unlearning' - to acknowledging 'how white racial privilege may affect our professional identity and beliefs in ways that present obstacles to transformative learning' (Yoon, 2012, 588). We see this research as a first step towards encouraging such an engagement by the wider profession ${ }^{\text {vii }}$.

\section{Disclosure Statement}

No potential conflict of interest was reported by the authors.

Funding

This research has been funded by a British Academy Leverhulme Small Grant.

\section{Acknowledgements}

We would like to thank all the participants for giving up their time and being involved in the research.

\section{References}

Azzarito, L. (2009). The Panopticon of physical education: pretty, active and ideally white. Physical Education and Sport Pedagogy, 14(1), 19-40. 
Beidlid, H. (2012). Et ekskluderende "vi"? verdier, kulturer og kulturarv i læreplanens generelle del og i formålsparagrafen: nasjonalt felleskap, multikulturalitet og kulturell kompleksistet. A 'we' that excludes? Values, cultures and cultural inheritance in the national core curriculum: a national commonality, multiculturalism and cultural complexity. Acta Didactica Norge, 6(1), Art 15.

BLI/ Barne-, 1. o. i. (2013). Lov om forbud mot diskriminering på grunn av etnisitet, religion og livssyn (diskrimineringsloven om etnisitet)

https://lovdata.no/dokument/NL/lov/2013-06-21$60 ? q=l o v+o m+$ forbud + mot + diskriminering.

Bryan, A. (2012). 'You've got to teach people that racism is wrong and then they won't be racist': Curricular representations and young people's understandings of 'race' and racism. Journal of Curriculum Studies,, 44(5), 599-629.

Carrington, B. (2001). Fear of a Black Athlete: Masculinity, politics and the body. New Formations, 45 (Winter), 91-11-.

Commission for Racial Equality. (2002). The duty to promote race equality; a guide for further and higher education [Internet]. London: Commission for Racial Equity. Available from: www.cehr.gov.uk, [Accessed 2nd Feb 2008].

Dagkas, S., Benn, T., \& Jawad, H. (2007). Multiple voices: Improving Participation of Muslim Girls in Physical Education and School Sport. Sport, Education and Society, 11, 21-38.

Davies, B., \& Gannon, S. (2006). Doing Collective Biography. Maidenhead: Open University Press. 
Department for Education. (2014a). Promoting fundamental British values as part of spiritual, moral, social and cultural development [internet].

Department for Education. (2014b). Schools, pupils and their characteristics: January 2014, National Statistics Report. Retrieved from London:

Dillabough, J. A., \& Acker, S. (2002). Globalisation, Women's work and Teacher Education: a cross-national analysis. International Journal of Sociology of Education, 12(3), 227-260.

Douglas, D., \& Halas, J. (2013). The wages of whiteness: confronting the nature of the ivory tower racism and the implications for physical education. Sport Education and Society, 18(4), 453-474.

Dowling, F., \& Flintoff, A. (2015). A whitewashed curriculum? The construction of race in contemporary PE curriculum policy. Sport, Education and Society, doi: 10.1080/13573322.2015.1122584.

Dyer, K. (1997). White: Essays on Race and Culture. London: Routledge.

Essed, P. (2005). Gendered preferences in racialized spaces: cloning the physician. In K. Murji \& J. Solomos (Eds.), Racialization. Studies in theory and practice (pp. 227248). Oxford: Oxford University Press.

Evans, J. (2004). Making a difference? Education and 'ability' in physical education. European Physical Education Review, 10(1), 95-108.

Evans, J., \& Davies, B. (2006). Social class and physical education. In D. Kirk, D. Macdonald, \& M. O'Sullivan (Eds.), The Handbook of Physical Education (pp. 796808). London: Sage. 
Fitzpatrick, K. (2013). Brown bodies, racialisation and physical education. Sport, Education and Society, 18(2), 135-153.

Flintoff, A. (2013). Tales from the playing field: black and minority ethnic students' experiences of physical education teacher education. Race, Ethnicity \& Education,, 17(3), 2-22. doi:10.1080/13613324.2013.832922

Flintoff, A., \& Fitgerald, H. (2012). Theorizing difference and in(equality) in physical education, youth sport and health. In F. Dowling, H. Fitzgerald, \& A. Flintoff (Eds.), Equity and difference in physical education, youth sport and health: A narrative approach (pp. 11-36). London: Routledge.

Flintoff, A., \& Dowling, F. (2014). Teachers, Whiteness and Racism: Examining Physical Educators’ Perspectives. British Academy/Leverhulme Small Grant, SG131853.

Dowling, F., \& Flintoff, A. (2016). Whiteness and (Anti) Racism in Physical Education: A Professional Development Resource. Norwegian School of Sport Sciences, Oslo/ Leeds, Leeds Beckett University.

Flintoff, A., Dowling, F., \& Fitzgerald, H. (2014). Working through whiteness, race and (anti)racism in physical education teacher education Physical Education and Sport Pedagogy, 20(5), 559-570. doi:10.1080/17408989.2014.962017

Gabriel, J. (1998). Whitewash: racialized politics and the media. London: Routledge.

Gaine, C. (2001). If it's not hurting it's not working: teaching teachers about 'race'. Research Papers in Education, 16(1), 93-113.

Garner, S. (2007). Whiteness. An Introduction. . London: Routledge

Gillborn, D. (2008). Racism and Education: Coincidence or Conspiracy? London: Routledge. 
Gillborn, D., \& Mirza, H. (2000). Education inequality: Mapping race, class and gender: a synthesis of research evidence. London: Office for Standards in Education.

Gullestad, M. (2006). Plausible prejudice. Everyday expeiences and social images of nation, culture and race. Oslo: Universitetsforleget.

Harlap, Y and Riese, H. 82014) hva skjer når vi ser farge innen utdanning? Mulighetene ved å teoretisere rase i skolen i et 'fargeblindt' Norge. In K. Westrheim and A. Tolo (Eds) Kompetanse for mangfold. Pp.190-216. Bergen: Fagbokforlaget.

House of Commons Library. (2014). National curriculum review [Internet].

Hylton, K. (2008). 'Race'and Sport: Critical Race Theory. London: Routledge.

Hylton, K. (2012). 'Talk the Talk, Walk the Walk: Defining Critical Race Theory in Research. Race, Ethnicity \& Education, 15(1), 23-41.

Hylton, K. (2015). 'Race' talk! Tensions and contradictions in sport and PE. Physical Education and Sport Pedagogy, 20(5), 503-516.

Johnson Lachuk, A., \& Mosley, M. (2011). Us and Them? Entering a three-dimensional narrative inequiry space with white pre-service teachers to explore race, racism and anti-racism. Race, Ethnicity and Education, DO!: 10.1080/13613324.2011.578123, 1-20.

Kirk, D., \& Vertinskyj, P. (Eds.). (2016). 'Women First' Revisited: Revisiting the Female Tradition in Physical Education. London: Routledge.

Lander, V. (2014). Initial Teacher Education: The Practice of Whiteness. In R. Race \& V. Lander (Eds.), Advancing Race and Ethnicity in Education (pp. 93-110). Basingstoke: Macmillan. 
Levine-Rasky, C. (2000). Framing Whiteness: working through the tensions in introducing whiteness to educators. Race, Ethnicity and Education, 3(3), 271-292.

Levine-Rasky, C. (2002). Introduction. In C. Levine-Rasky (Ed.), Working through whiteness: international perspectives (pp. 1-22). Albany: New York Press.

Levine-Rasky, C. (2013). Whiteness Fractured. Farnham: Ashgate.

Long, J., Hylton, K., Sparklen, K., Ratna, A., \& Bailey, S. (2009). Systematic Review of Literature on Black and Minority Ethnic Communities in sport and physical recreation. Retrieved from Leeds:

McDonald, B. (2013). The reproduction of biological 'race' through physical education textbooks and curriculum. European Physical Education Review, 19(2), 183-198.

McKinney, K., D. (2005). Being White:: Stories of Race and Racism. London: Routledge.

McLeod, J., \& Thomson, R. (2009). Researching Social Change: Qualitative Approaches, London, Sage.

London: Sage National College for Teaching and Leadership. (2015). Newly qualified teachers annual survey: research report [internet].

NOU/Norges offentlig utredninger 2014:7. Elevenes læring i fremtidens skole. Et kunnskapsgrunnlag. (Students' learning in tomorrow's school)

Norges offentlige utredninger. (2010). Mangfold og mestring. Flerspraklige barn, unge og voksne i opplaeringssysternet. (Diversity and mastery). Retrieved from

Pearce, S. (2003). Compiling the White Inventory: the practice of whiteness in a British primary school. Cambridge Journal of Education, 33(2), 273-288. 
Pennington, J., \& Prater, K. (2014). The veil of professionalism: An autoethnographic critique of white professional identities in the figured world of white performance. Race, Ethnicity \& Education, http://dx.doi.org/10.1080/13613324.2014.885431.

Pheonix, A. (2009). De-colonising practices: negotiating narratives from racialised and gendered experiences of education. Race Ethnicity and Education, 12(1), 101-114.

Picower, B. (2009). The unexamined Whiteness of teaching: how White teachers maintain and enact dominant racialised ideologies. Race, Ethnicity and Education, 12(2), $197-215$.

Skrefsrud, T.-A. og Østberg, S. (2015). Diversitet i lærerutdanningene - bidrag til en profesjonsorientert forståelse av fag og kunnskapsområder. Norsk pedagogisk tidsskrift, 3:208-219

Smith, H. (2013). A critique of the teaching standards in England (1984-2012). Journal of Educational Policy, 28(4), 427-448.

Tomlinson, S. (2008). Race and education: policy and politics in Britain. Maidenhead, Berkshire: Open University.

Van Doodewaard, C., \& Knoppers, A. (2016). Perceived differences and preferred norms: Dutch physical educators constructing gendered ethnicity. Gender and Education, DOI: 10.1080/09540253.2016.1188197.

Walseth, K. (2013). Muslim girls' experiences in physical education in Norway: what role does religiosity play? Sport, Education and Society, $20(3$ ), 304-322 doi:10.1080/13573322.2013.769946 
Webb, L. A., \& Macdonald, D. (2007). Techniques of power in physical education and the under-representation of women in leadership. Journal of Teaching in Physical Education,, 26(3), 277-295.

Wilkins, C. (2014). Inspecting the Inspectors: race equality and quality in initial teacher education. Race, Ethnicity \& Education, 17(3), 445-470.

Yoon, I. (2012). The paradoxical nature of whiteness-at-work in the daily life of schoosl and teacher communities. Race, Ethnicity and Education, 15(5), 587-613.

\footnotetext{
i $25 \%$ of English pupils attending state funded secondary schools come from a black and minority ethnic (BME) background; (30\% at primary level); however schools' intakes differ significantly and in key conurbations, BME pupils will be in the majority (Burgess et al 2005). In Norway, similar patterns exist whereby some urban schools have large overrepresentations of 'immigrant' students.

${ }^{i i}$ Race and ethnic difference are addressed differently at institutional and state level. For example, whilst ethnic monitoring in the UK is seen as part of good practice, and by legislation, a requirement of all public bodies in order to help promote positive race relations, in Norway, this is not the case. 'Norwegians' are those born in the country, and those who are not, classified as 'immigrants' (Gullested 2006).

iii Following Levine-Rasky (2002) we use 'racialised other' rather than terms such as 'BME' to refer to those groups that have been regarded as distinct from white, thus ensuring a link between racialisation and racism. Where citing others' work, we use their terminology.

${ }^{\text {iv }}$ Space prevents a detailed analysis of our own postionality here, but see (Flintoff and Webb, 2012; Flintoff, et al, 2014).

${ }^{v}$ Apart from our names as authors, all others are pseudonyms.

${ }^{v i}$ Significant legal changes in the UK introduced in 2000 recognised the institutionalised nature of racism is explicitly recognised and schools and universities now have a legal requirement to actively promote positive race relations through their policy/practice as well as recording and reporting on racist incidents.

vii To this end, we have drawn on the research to develop some pedagogical materials that might prove useful to others wishing to engage in the task of dismantling whiteness (see Dowling and Flintoff, 2016).
} 